\title{
OMEPRAZOLE, FURAZOLIDONE, AND TETRACYCLINE: AN ERADICATION TREATMENT FOR RESISTANT $H$. PYLORI IN BRAZILIAN PATIENTS WITH PEPTIC ULCER DISEASE
}

Fernando Marcuz Silva, Jaime Natan Eisig, Ethel Zimberg Chehter, Júlio Jovino da Silva and Antonio Atílio Laudanna

RHCFAP/3094

SILVA FM et al. - Omeprazole, Furazolidone, and Tetracycline: an eradication treatment for resistant $H$. pylori in Brazilian patients with peptic ulcer disease. Rev. Hosp. Clín. Fac. Med. S. Paulo 57(5):205-208, 2002.

OBJECTIVES: To determine the efficacy of a simple, short-term and low-cost eradication treatment for Helicobacter pylori (H. pylori) using omeprazole, tetracycline, and furazolidone in a Brazilian peptic ulcer population, divided into 2 subgroups: untreated and previously treated for the infection.

PATIENTS AND METHODS: Patients with peptic ulcer disease diagnosed by endoscopic examination and infected by $H$. pylori diagnosed by the rapid urease test (RUT) and histological examination, untreated and previously unsuccessfully treated by macrolides and nitroimidazole, were medicated with omeprazole $20 \mathrm{mg}$ daily dose and tetracycline $500 \mathrm{mg}$ and furazolidone $200 \mathrm{mg}$ given 3 times a day for 7 days. Another endoscopy or a breath test was performed 12 weeks after the end of treatment. Patients were considered cured of the infection if a RUT and histologic examination proved negative or a breath test was negative for the bacterium.

RESULTS: Sixty-four patients were included in the study. The women were the predominant sex (58\%); the mean age was 46 years. Thirty-three percent of the patients were tobacco users, and duodenal ulcer was identified in $80 \%$ of patients. For the 59 patients that underwent follow-up examinations, eradication was verified in $44(75 \%)$. The eradication rate for the intention-to-treat group was $69 \%$. The incidence of severe adverse effects was $15 \%$.

CONCLUSION: The treatment provides good efficacy for $H$. pylori eradication in patients who were previously treated without success, but it causes severe adverse effects that prevented adequate use of the medications in $15 \%$ of the patients.

DESCRIPTORS: Peptic Ulcer. Treatment. Helicobacter pylori. Eradication. Tetracycline. Furazolidone. Omeprazole.

\section{INTRODUCTION}

The eradication of $H$. pylori in patients with peptic ulcer disease linked to such bacterium cures the disease $\mathrm{e}^{1,2}$. At present, the treatments for $H$. pylori eradication consist of the association of 2 antibiotics with an acid supressor ${ }^{3-5}$. Clarithromycin and amoxicillin with a proton pump inhibitor or clarithromycin with or without amoxicillin and bismuth-ranitidine provide high eradication rates in Brazil ${ }^{6,7}$. For the patients in whom the bacterium cannot be eradicated, considering the high prevalence of primary resistance to nitroimidazoles in our country ${ }^{8}$ and the expected secondary resistance to macrolides ${ }^{9}$, the furazolidone option ${ }^{10,11}$ is attractive, due to its low cost and high efficacy, and it has been proposed as the first or

From the Department of Medicine and the Department of Clinical Gastroenterology, Hospital das Clínicas, Faculty of Medicine, University of São Paulo. second choice of treatment ${ }^{12-22}$.

The aim of this study was to test the efficacy of a treatment schedule that uses furazolidone with tetracycline and omeprazole for 7 days in untreated peptic ulcer patients and in those previously treated without success using nitroimidazoles and macrolides.

\section{PATIENTS AND METHODS}

Patients with a diagnosis of scarred 
or active gastric or duodenal peptic ulcer disease, confirmed by upper digestive endoscopy, performed at the Gastroenterology Unit of São Paulo University Medical School Hospital, and infected by $H$. pylori were invited to participate in the study. Patients untreated for $H$. pylori infection or previously treated without success for the infection with nitroimidazoles and macrolides were included in the study. Patients with prior antibiotic therapy up to 3 months prior to the study start date, patients under 14 years old, patients with severe disease, pregnant or lactating patients, and patients with prior gastric surgery were excluded. The Hospital Committee on Ethics and Science approved the study, and all patients signed the informed consent statement.

\section{Infection diagnosis:}

Diagnosis of $H$. pylori infection was made by histologic examination in all cases, (H \& E staining), and the rapid urease test (RUT) ${ }^{23}$ was performed on mucosal biopsy specimens of the gastric antrum that were obtained through upper digestive endoscopy.

\section{Treatment:}

Treatment consisted of tetracycline $500 \mathrm{mg}$ and furazolidone $200 \mathrm{mg}$ administered 3 times a day after each meal, with omeprazole $20 \mathrm{mg}$ once a day before breakfast, for 7 days. At end of the treatment, patients were required to avoid all anti-ulcer medications, except for the symptomatic use of antacid pills. Patients were then questioned about the occurrence and intensity of adverse effects, and the remaining pills were counted.

\section{Treatment assessment:}

H. pylori infection was considered cured if TRU and the histologic examination by upper endoscopy performed 12 weeks after the end of treatment proved to be negative or a ${ }^{14} \mathrm{C}$-urea breath test ${ }^{24}$ performed 12 weeks after the end of treatment was negative.

Statistical determinations were made by SPSS, software package version 8.0 (SPSS Inc. USA).

\section{RESULTS}

The clinical data of the studied population are shown in table 1 . The female sex was predominant, and the percentage of duodenal ulcer was high. The mean age was similar to the median age. Smokers made up one third of the total patient number. Five patients did not show up for follow-up examinations. The eradication rates were good: $75 \%$ for the per protocol group (Table 2). The differences regarding eradication rates between the previously treated group (77\%) and the previously untreated group (74\%) did not reach statistical significance $(P=$ $0.71)$.

Adverse effects were reported by $34 \%$ of patients: $14 \%$ were of mild intensity and 5\% moderate intensity. Severe adverse effects, mainly nausea and vomiting episodes, were reported by $15 \%$ of the patients.

Table 1 - Clinical data of patients.

\begin{tabular}{llc}
\hline Patients & & 64 \\
Age (years) & Mean & 46 \\
& Median & 44 \\
& Interval & $14-75$ \\
Women & & $58 \%$ \\
Previously treated & & $60 \%$ \\
Duodenal ulcers & & $80 \%$ \\
Scarred ulcers & & $66 \%$ \\
Tobacco users & & $33 \%$ \\
Alcohol users & & $10 \%$ \\
\hline
\end{tabular}

\section{DISCUSSION}

Even though it is possible to effectively treat the symptoms of peptic ulcer disease using acid suppressors, treatment with antibiotics ${ }^{25}$ is more cost effective. Additionally, for complicated ulcers, the latter treatment also reduces risk of bleeding ulcers, stenosis ulcers, perforating ulcers, etc. ${ }^{26,27}$. Therefore, even when considering the greater difficulty in treating resistant $H$. pylori infection (the retreatment schedules are more complex, have lower efficacy, higher costs, and more frequent adverse effects ${ }^{28,29}$ ), it is important to seek effective treatment schedules for such cases. A high rate of primary resistance of $H$. pylori to nitroimidazole compounds ${ }^{8}$ and recently also amoxicillin ${ }^{9}$ has been described in our country. The low cost and simplicity of this treatment schedule are very important attributes for the eradication of $H$. pylori, if one considers the low cultural and social status and the low income of the majority of the Brazilian people. The choice of the treatment schedule with tetracycline, furazolidone, and omeprazole involved consideration of these issues. The eradication rate obtained for previously treated patients, which did not differ from that of untreated patients, can be considered satisfactory for a retreatment schedule.

The high incidence of adverse effects, also observed by another author ${ }^{14}$, is a noteworthy outcome of this study, especially considering the severity of the adverse effects. The treatment schedule with clarithromycin, tinidazole, and proton pump inhibi-

Table 2 - Eradication rates.

\begin{tabular}{lcc}
\hline & $\mathrm{n} / \%$ & Confidence Interval (95\%) \\
\hline Per protocol & $44 / 59(\mathbf{7 5 \%})$ & $63 \%-86 \%$ \\
Intention to treat & $44 / 64(\mathbf{6 9 \%})$ & $57 \%-80 \%$ \\
\hline
\end{tabular}


tor $^{30}$ resulted in $18 \%$ adverse effects, and only 1 patient discontinued the medications. This fact was a possible limitation for the achievement of better eradication rates. Adverse effects are more frequently related to furazolidone use ${ }^{14}$, a main drug of the treatment schedule in our study. The addition of another drug to prevent adverse effects, if possible, will change this schedule into a new complex one. Nevertheless, this treatment does not promote secondary bacterial resistance to the antibiotics ${ }^{31}$, and it is a shortterm and low-cost treatment; therefore, it is an interesting option for a great number of Brazilian patients with peptic ulcers due to $H$. pylori infection, particularly those who have antibioticresistant infection.

\section{ACKNOWLEDGMENTS}

The authors would like to thank Bristol-Myers Squibb Brasil S/A for supplying tetracycline and Uci-Farma Indústria Farmacêutica Ltda for supplying furazolidone and omeprazole.
SILVA FM e col. - Omeprazol, Tetraciclina e Furazolidona, um tratamento para erradicação do $H$. pylori resistente em pacientes ulcerosos do Brasil. Rev. Hosp. Clín. Fac. Med. S. Paulo 57(5): 205-208, 2002.

OBJETIVO: Testar a eficácia de um esquema simplificado e de baixo custo para erradicação do $H$. pylori utilizando omeprazol, tetraciclina e furazolidona, em uma população de ulcerosos do Brasil, já tratados e não tratados previamente para a infecção.

PACIENTES E MÉTODOS: Pacientes portadores de úlcera péptica, documentada por exame endoscópico e infectados pelo $H$. pylori confirmado pelo teste da urease e exame histológico, não tratados previamente ou já tratados sem sucesso com macrolídeos e nitroimidazólicos, foram tratados com Omeprazol 20mg em dose única diária, associado à Tetraciclina 500mg e Furazolidona 200mg dadas três vezes ao dia, por três dias. Uma nova endoscopia ou um Teste Respiratório foi realizado 12 semanas após o término do tratamento e foram considerados erradicados da infecção os pacientes que apresentaram o teste da urease e exame histológico negativos ou o Teste Respiratório negativo para a bactéria.

RESULTADOS: Sessenta e quatro pacientes foram incluídos no estudo, 26 deles não previamente tratados. As mulheres predominaram (58\%), a idade média foi de 46 anos, 33\% dos pacientes eram tabagistas e a úlcera duodenal foi identificada em $80 \%$ dos pacientes. Nos 59 doentes que realizaram o exame de controle, a erradicação foi constatada em $44(75 \%)$. Por intenção de tratamento o índice foi de $68 \%$. O grupo não tratado previamente não diferiu do grupo previamente tratado. A incidência de efeitos adversos intensos foi de $15 \%$.

CONCLUSÃO: O esquema proporciona boa eficácia na erradicação do H. pylori em pacientes já previamente tratados sem sucesso, porém apresenta efeitos adversos intensos, que impediu o uso adequado dos medicamentos em $15 \%$ dos pacientes.

DESCRITORES: Úlcera Péptica. Tratamento. Helicobacter pylori. Erradicação. Tetraciclina. Furazolidona. Omeprazol.

\section{REFERENCES}

1. PENSTON JG - Review article: clinic aspectcs of Helicobacter pylori eradication therapy in peptic ulcer disease. Aliment Pharmacol Ther 1996; 10(suppl 4): 469-86.

2. TYTGAT GN - Treatment of peptic ulcer. Digestion 1998; 59: 446-52.

3. GODDARD AF, SPILLER RC - Helicobacter pylori eradication in clinical practice: one-week low-dose triple therapy is preferable to classical bismuth based triple therapy. Aliment Pharmacol Ther 1996; 10:1009-13.
4. UNGE P, BERSTAD A - Pooled analysis of anti-Helicobacter pylori treatment regimens. Scand J Gastroentrol 1996; 31(suppl 220): 27-40.

5. VAN DER HULST RWM, KELLER JJ, RAWUS EAJ et al. Treatment of Helicobacter pylori infection: A review of the World literature. Helicobacter 1996; 1: 6-19.

6. VAN OIJEN AHAM, VERBEEK AL, JANSEN JBMJ - Review article: treatment of Helicobacter pylori infection with ranitidine bismuth citrate or proton pump inhibitor-based triple therapies. Aliment Pharmacol Ther 2000; 14: 991-9 
7. CHEHTER EZ, SILVA FM, EISIG JN et al. - H. pylori eradication: High efficacy week treatment with clarithromycin $500 \mathrm{mg}$ bid, amoxicillin $1.0 \mathrm{~g}$ bid plus lansoprazole $30 \mathrm{mg}$ bid in São Paulo - Brazil. Am J Gastroenterol 1999; 94: A118

8. QUEIROZ DMM, COIMBRA RS, MENDES EN ROCHA et al. Metronidazole-resistant Helicobacter pylori in a developing country. Am J Gastroenterol 1993; 88: 322-3

9. BUCKLEY MJM, XIA HX, HYDE DM et al. - Metronidazole resistance reduces efficacy of triple therapy and leads to secondary clarithromycin resistance. Dig Dis Sci 1997; 42: 2111-5.

10.KWON DH, LEE M, KIM JJ et al. - Furazolidone- and nitrofurantoin-resistant Helicobacter pylori: prevalence and role of genes involved in metronidazole resistance. Antimicrob Agents Chemother. 2001; 45: 306-8.

11.MENDONÇA S, ECCLISSATO C, SARTORI MS et al. - Prevalence of Helicobacter pylori resistance to metronidazole, clarithromycin, amoxicillin, tetracycline, and furazolidone in Brazil. Helicobacter. 2000; 5: 79-83.

12.GUSLANDI M - Review article: alternative antibacterial agents for Helicobacter pylori eradication. Aliment Pharmacol Ther 2001; 15:1543-7.

13.SEGURA AM, GUTIÉRREZ O, OTERO W et al. - Furazolidone, amoxycillin, bismuth triple therapy for Helicobacter pylori infection. Aliment Pharmacol Ther 1997; 11: 529-32.

14.GRAHAM DY, OSATO MS, HOFFMAN J et al. - Furazolidone combination therapies for Helicobacter pylori infection in the United States. Aliment Pharmacol Ther 2000; 14: 211-5.

15.MARSHALL BJ - When Helicobacter pylori $(h p)$ eradication fails: what to do next? J Gastroenterol Hepatol 2000; 15: pH30.

16.DANI R, QUEIROZ DM, DIAS MG et al. - Omeprazole, clarithromycin and furazolidone for the eradication of Helicobacter pylori in patients with duodenal ulcer. Aliment Pharmacol Ther 1999, 13: 1647-52.

17.ZATERKA S, EISIG JN, CHINZON D et al. - Five-day and tenday triple therapy (amoxicillin, furazolidone and metronidazole) in the treatment of duodenal ulcer. Rev Hosp Clin Fac Med S Paulo 1996; 51: 162-5.

18.COELHO LG, PASSOS MC, CHAUSSON Y et al. - Duodenal ulcer and eradication of Helicobacter pylori in a developing country. An 18-month follow-up study. Scand J Gastroenterol 1992, 27: $362-6$.
19.FAKHERI H, MALEKZADEH R, MERAT, S et al. - Clarithromycin vs. furazolidone in quadruple therapy regimens for the treatment of Helicobacter pylori in a population with a high metronidazole resistance rate. Aliment Pharmacol Ther 2001, 15: 411-6.

20.DROUIN E - Helicobacter pylori: novel therapies. Can J Gastroenterol 1999; 13:581-3.

21.XIAO SD, LIU WZ, HU PJ et al. - A multicentre study on eradication of Helicobacter pylori using four 1-week triple therapies in China. Aliment Pharmacol Ther 2001; 15: 81-6.

22.XIAO SD, LIU WZ, HU PJ et al. - High cure rate of Helicobacter pylori infection using tripotassium dicitrato bismuthate, furazolidone and charithoymcin triple therapy for 1 week. Aliment Pharmacol Ther 199; 13: 311-5.

23.MCNULTY CAM, WIS R - Rapid diagnosis of Campilobacter pylori. Lancet 1985 ; 1: 1443-4.

24.MATTAR R, SILVA FM, ALEXANDRINO AM et al. - Validation of ${ }^{14} \mathrm{C}$-urea breath test for diagnosis of Helicobacter pylori $\mathbf{R e v}$ Inst Med Trop S. Paulo 1999; 41: 3-8.

25.SONNENBERG A, TOWNSEND WF - Costs of duodenal ulcer therapy with antibiotics. Arch Intern Med 1995; 155: 922-8.

26.LAINE LA - Helicobacter pylori and complicated ulcer disease. Am J Med 1996; 100: 52S-57S

27.GRAHAM DY, LEW GM, KLEIN PD et al. - Effect of treatment of Helicobacter pylori infection on the long-term recurrence of gastric or duodenal ulcer. A randomized, controlled study. Ann Intern Med 1992; 116: 705-8.

28.HOJO M, MIWA H, NAGAHARA A et al. - Pooled analysis on the efficacy of the second-line treatment regimens for Helicobacter pylori infection. Scand J Gastroenterol 2001; 36 :690-700.

29.GISBERT JP, BOIXEDA D, BERMEJO F et al. - Re-treatment after Helicobacter pylori eradication failure. Eur J Gastroenterol Hepatol 1999; 11 :1049-54.

30.SILVA FM, ZATERKA S, NATAN JE et al. - Factors affecting Helicobacter pylori eradication using a seven-day triple therapy with a proton pump inhibitor, tinidazole and clarithomycin, in Brazilian patients with peptic ulcer. Rev Hosp Clin Fac Med S. Paulo 2001; 56: 11-16.

31.HAAS CE, NIX DE, SCHENTAG JJ - In vitro selection of resistan Helicobacter pylori. Antimicrob Agents Chemother 1990; 34: 1637-41.

Received for publication on December 06, 2001. 